\title{
Особливості цитокінового профілю та імунного статусу у хворих на кондиломи аногенітальної ділянки
}

\begin{abstract}
Мета роботи: вивчити зміни клітинного та гуморального імунітету у хворих на гострокінцеві кондиломи аногенітальної ділянки та визначити ступінь порушень; дослідити стан цитокінового профілю у хворих на ГК аногенітальної ділянки як факторів прогнозування перебігу післяопераційного періоду та ефективності лікування.

Матеріали і методи. Обстежено 105 хворих на ГК аногенітальної ділянки: 63 (60 \%) жінки та 42 (40 \%) чоловіки. Вивчено стан клітинного та гуморального імунітету та рівень цитокінів TNFa, IL-4, IL-6, IL-8.

Результати досліджень та їх обговорення. Частота хронічних соматичних захворювань склала 96 (91,43 \%). Визначено достовірне зниження абсолютної та відносної кількості лімфоцитів та їх Т-популяцій. На тлі Т-лімфопенії визначено підвищення рівня В-лімфоцитів (CD22) в абсолютній та відносній кількості та Ig A та Ig G, що свідчить про наявність хронічного запального процесу та / або вірусного запалення з виснаженням Т-ланки імунітету. Рівень IL-4 був вищим, ніж у контрольній у 2,4 раза, та

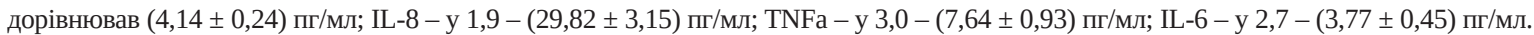
Виявлено залежність рівня TNFa, IL-6, IL-4 та IL-8 від розповсюдження гострокінцевих кондилом та присутності супутнього перифокального запалення з найвищими значеннями при кондиломах Бушке-Левенштейна, тоді як у хворих на поодинокі гострокінцеві кондиломи цитокіновий профіль не відрізнявся від контрольної групи.

У хворих на гострокінцеві кондиломи аногенітальної ділянки зсуви в ланках клітинного та гуморального імунітету характеризуються виснаженням ланки клітинного імунітету - загальною лімфопенією, Т-лімфопенією зі зниженням їхньої абсолютної та відносної кількості в усіх субпопуляціях, підвищенням рівня B-лімфоцитів, Ig G тa Ig A. Підвищення рівня цитокінів IL-4, IL-6, IL-8 та TNFa у хворих на ГК аногенітальної ділянки відображає ступінь розповсюдження гострокінцевих кондилом та відповідає характеру перифокального запального процесу, що доцільно використовувати як фактор прогнозування перебігу післяопераційного періоду та ефективності лікування.
\end{abstract}

Ключові слова: вірус папіломи людини; гострокінцеві кондиломи; цитокіновий профіль; імунологічний статус.

Постановка проблеми і аналіз останніх досліджень та публікацій. У світі, за даними ВООЗ, щорічно реєструють більше 300 млн епізодів захворювань, що передаються статевим шляхом, 3 тенденцією до зростання захворювань вірусної етіології, а саме вірусом папіломи людини (ВПЛ) [3]. Нині захворювання, спричинені ВПЛ, є найбільш розповсюдженою інфекційною патологією. При цьому їх поширення не обмежується традиційною групою ризику (особами, які часто змінюють статевих партнерів, наркоманами тощо), а охоплює різні прошарки та вікові групи суспільства. Взагалі розповсюдженість ВПЛ серед населення варіює від 4 до 35 \%, залежить від низки факторів [2-4] і в гендерному співвідношенні серед дорослого населення віком18 - 59 років складає до 45,2 \% у чоловіків та 39,9 \% у жінок [10, 12]. Це зумовлено високою контагіозністю вірусу, зараження яким може відбутися навіть при одному незахищеному контакті, та становить 60-70 \% випадків [9, 11]. Але ці дані відображають лише статистику клінічних проявів, тоді як субклінічні та латентні форми не реєструються. Як різновид опортуністичної інфекції, що маніфестує та прогресує на тлі зсувів імунного гомеостазу, ВПЛ ін- дукує широкий спектр захворювань передпухлинного та пухлинного генезу: уражає епітелій шкіри, статевих органів, слизових оболонок респіраторного тракту людини, аногенітальної ділянки, ротової порожнини, стравоходу та має різноманітні форми [1, 4].

Клінічними проявами ВПЛ, що спричиняється серотипами з низькою онкогенністю $(6,11$ серотипи) [9], є гострокінцеві кондиломи (ГК) аногенітальної ділянки, частота яких займає третє місце серед захворювань, що передаються статевим шляхом [6, 7]. Вони належать до ВПЛ, які складають групу екзофітних кондилом (типові гострокінцеві кондиломи, пласкі кондиломи, ураження у вигляді плям, гігантські кондиломи Бушке - Левенштайна, бовеноїдний папульоз), що характеризується екзофітним ростом, хронічним перебігом та низькою онкогенністю [3].

Водночас не існує лікарських засобів, що забезпечують повну елімінацію ВПЛ з організму людини, а відомі засоби, що пригнічують реплікацію вірусу простого герпесу, виявилися не ефективними при лікуванні ГК. Встановлено, що після деструкції ГК вірус продовжує тривало зберігатися у зовні здоровому епідермісі, призводячи до 


\section{З ДОСВІДУ РОБОТИ}

частих рецидивів, частота яких становить від 50 до 94 \%. Це пояснює різний ступінь вірусного навантаження, супутню хронічну патологію, зсуви в імунній відповіді та в подальшому визначає прогноз $[3,4]$.

Мета роботи: вивчити зміни клітинного та гуморального імунітету у хворих на ГК аногенітальної ділянки та визначити ступінь порушень; дослідити стан цитокінового профілю у хворих на ГК аногенітальної ділянки як факторів прогнозування перебігу післяопераційного періоду та ефективності лікування.

Матеріали і методи. Для досягнення мети ми обстежили та пролікували 105 хворих на ГК аногенітальної ділянки, серед яких поодинокі ГК - 36 (34,29 \%); множинні ГК - 66 (62,86 \%); гігантські кондиломи Бушке-Левенштейна - 3 (2,86 \%). Контрольну групу склали 20 осіб. В гендерному співвідношенні основну групу склали 63 (60 \%) жінки та 42 (40 \%) чоловіки. В контрольній - 10 (50 \%) жінок та 10 (50 \%) чоловіків. Критерієм виключення з основної групи були наявність цукрового діабету, вагітності, ВІЛ, сифілісу, онкологічної патології шкіри аногенітальної ланки, прямої кишки, статевих органів.

Оцінку імунного статусу обстежених проводили в процесі дослідження клітинної і гуморальної ланок імунітету. Дослідження імуноглобулінів класів A, M, G здійснювали за методикою Манчіні (1965). Дослідження кількості Т- і В-лімфоцитів, Т-хелперів, Т-супресорів проводили за методом із моноклональними антитілами IKO-80, IKO-86, IKO-31, IKO-12 [8]. Рівень цитокінів TNFa, IL-4 IL-6 IL-8 визначали з використанням твердофазного імуноферментного методу з моноклональними та поліклональними антитілами.

Математичну обробку результатів дослідження здійснювали за допомогою ліцензійних програмних продуктів, які входять до пакету Microsoft Office Professional 2000. Для чисельних даних варіаційного ряду розраховували середнє арифметичне (M), середню помилку середнього арифметичного ( $\pm \mathrm{m})$ та коефіцієнт варіації $\left(\mathrm{V}_{\sigma}\right)$. $\mathrm{V}_{\sigma}<10 \%$ - незначне коливання, сукупність однорідна, значення середньої $є$ типовим рівнем ознаки в даній сукупності; $10 \% \leq \mathrm{V}_{\sigma} \leq 33 \%$ - середнє коливання, сукупність у межах однорідності, значення середньої можна вважати типовим рівнем ознаки в даній сукупності; $\mathrm{V}_{\sigma}>33$ \% - високий рівень варіації, сукупність неоднорідна, значення середньої не можна вважати типовим рівнем ознаки в даній сукупності [5]. Порівняльну оцінку значимості відмінностей між основною та контрольною групами проводили за t-критерієм Стьюдента (розрахунок між варіаційними рядами, що не пов'язані). Інтервал надійності отримували з вірогідністю 95 \% (р < 0,05).

Результати досліджень та їх обговорення. При аналізі соматичного статусу хворих на ГК аногенітальної ділянки виявлено високий рівень хронічних захворювань, які спостерігали у 96 (91,43 \%). Тоді як 24 (22,86 \%) пацієнти вважали себе соматично здоровими, тобто не зверталися по медичну допомогу, що сприяло хронізації патології. Привертає увагу висока частота патології системи травлення, що становила 81 (77,14%). Серед даної групи хронічний холецистит діагностували у 45 (42,86 \%), хронічний гастрит - 65 $(61,90)$, виразка шлунка та дванадцятипалої кишки - 9 (8,57 \%), хронічний (не вірусний) гепатит - 7 (6,67 \%), захворювання прямої кишки - 53 (50,48 \%), синдром подразненого кишечника - 31 (29,52 \%), закрепи з нез' ясованою етіологією - 17 (16,19 \%). Захворювання легень - 25 (23,81 \%), алергічні захворювання - 41 (39,05 \%), автоімунні захворювання - 3 (2,86 \%), вірусні, бактеріальні та грибкові ураження шкіри - 31 (29,52 \%), анемія легкого ступеня - 31 (29,52 \%). В середньому на одного хворого основної групи припадало 2,16 випадка патології травної системи та 3,41 - загальної соматичної патології.

На відміну від основної групи, в контрольній рівень соматичної патології був достовірно нижчим. Частота хронічного холециститу була менше у 2,14 раза та дорівнювала 4 (20 \%) (р < 0,05), хронічного гастриту у 2,58 - 5 (25,0 \%) (p < 0,05), захворювань прямої кишки у 1,68 - 6 (30,0%) (р < 0,05), синдрому подразненого кишечника - у 2,95 - $2(10,0 \%)$ ( $<0,05)$, закрепів із нез'ясованою етіологією - у 3,22 - 1 (5,0 \%) (p < 0,05). Захворювань легень - у 4,7 - 1 (5,0 \%) (p < 0,05), алергічних захворювань - у 2,6-3 (15,0%) (р < 0,05), вірусних, бактеріальних і грибкових захворювань шкіри - у 2,95 - 2 (10,0 \%) ( $<0,05)$. Автоімунні захворювання, виразка шлунка та дванадцятипалої кишки, анемії, хронічний гепатит - не зустрічалися. Частота ГРВI в обох групах мала сезонний характер та не відрізнялася від популяційних показників. В середньому в контрольній групі на одного обстеженого припадало 0,9 випадків патології травної системи та 1,2 загальної соматичної патології (р < 0,05).

Таким чином, у хворих на ГК аногенітальної ділянки рівень хронічної соматичної та інфекційної патології був достовірно вищим, що дає підставу думати про присутність хронічних імунних 
розладів, які є фактором ризику щодо розвитку ГК у інфікованих ПВЛ, та призводять до маніфестації патологічного процесу. У свою чергу, ВПЛ як опортуністична вірусна інфекція з високою вірогідністю ініціює подальший розвиток імунодефіцитних станів, знижує противірусний захист та сприяє персистенції вірусу.

При обстеженні імунного статусу у 100 \% хворих на ГК аногенітальної ділянки спостерігалася достовірно нижча, порівняно з контрольною групою, загальна кількість лімфоцитів, яка дорівнювала $(1,63 \pm 0,07) \times 10^{9} /$ л при $(2,15 \pm 0,1) \times 10^{9} /$ л ( $<$ < 0,05), що свідчить про однорідність групи за даною ознакою та може використовуватися як прогностичний фактор щодо перебігу захворювання. Відносна кількість лімфоцитів відповідала нижній границі референтних значень - $(28,75 \pm 1,75) \%$, тоді як у контрольній групі вона була вище в 1,3 раза та дорівнювала $(35,95 \pm 1,61) \%(\mathrm{p}<0,05)$. Наявність абсолютної та відносної лімфопенії можна пояснити з позицій впливу тривалої вірусемії на клітинний імунний гомеостаз.

При імунологічному обстеженні у хворих основної групи, порівняно 3 контрольною, було виявлено пропорційне зниження абсолютної кількості Т-лімфоцитів (CD3+) та їх популяцій. Кількість Т-лімфоцитів (CD3+) була нижчою у 1,6 раза та дорівнювала, відповідно, $(0,70 \pm 0,02) \times 10^{9} / л$ та $(1,13 \pm 0,07) \times 10^{9} / л(\mathrm{p}<0,05)$. Абсолютний рівень CD4+ (Т-хелперів / індукторів) порівняно 3 контрольною групою був знижений в 1,6 раза - $(0,42$ $\pm 0,01) \times 10^{9} /$ л при $(0,66 \pm 0,05) \times 10^{9} /$ л $(\mathrm{p}<0,05)$. Рівень CD8+ (Т-супресорів / кілерів) також відрізнявся та був нижче в 1,5 раза $-(0,28 \pm 0,01) \times 10^{9} / л$ при $(0,43 \pm 0,03) \times 10^{9} / л(\mathrm{p}<0,05)$ в контрольній.

Відносна кількість популяцій Т-лімфоцитів достовірно відрізнялась. Рівень CD3+ в основній групі дорівнював $(41,64 \pm 0,41) \%$; в контрольній $-(49,45 \pm 0,8) \%(\mathrm{p}<0,05), \mathrm{CD} 4+$ відповідно $(25,19 \pm 0,45) \%$ та $(30,15 \pm 0,64) \%(\mathrm{p}<0,05)$; за показниками CD8+ в основній $(16,48 \pm 0,36) \%$ та в контрольній $(19,40 \pm 0,52)(\mathrm{p}<0,05)$. У всіх обстежених встановлено дисбаланс субпопуляційного складу Т-лімфоцитів із їх пропорційним зниженням в 1,2 раза. При цьому рівень CD3+ було знижено відносно референтних значень у $100 \%$ хворих, що свідчить про статистичну однорідність сукупності. За показниками CD4+ зниження мали 33 (36,7 \%). Рівень CD8+ знижено у 29 (32,2 \%). Неоднорідність за цими показниками можна пояснити лише з позиції їх первинності відносно ВПЛ. Імунорегуляторний індекс достовірно не відрізнявся та в основній групі склав $(1,64 \pm 0,06) \%$, в контрольній $-(1,55 \pm 0,08) \%(p>0,05)$, але в основній групі його підвищення відносно референтних значень спостерігали у 18 (20,0 \%), тоді як у контрольній лише в одному випадку (5 \%) за рахунок зниження.

Водночас на тлі Т-лімфопенії було змінено рівень В-лімфоцитів (CD22) в абсолютному та відносному форматах. Підвищення загальної кількості В-лімфоцитів відносно референтних значень встановлено у 81 (90 \%) хворого основної групи та лише у $3(15 \%)(\mathrm{p}<0,05)$ у контрольній зі значеннями, відповідно, $(0,52 \pm 0,02) \times 10^{9}$ та $(0,45 \pm 0,03)$ $\times 10^{9}$ (р > 0,05). Спостерігали зміни і відносного складу в бік збільшення: $(30,41 \pm 0,52) \%$ при $(20,4$ $\pm 0,38) \%$ в контрольній $(\mathrm{p}<0,05)$, що свідчить про наявність хронічного запального процесу та / або вірусного запалення з виснаженням Т-ланки імунітету.

Відповідно до підвищення В-лімфоцитів ми спостерігали зміни в ланці гуморального імунітету. За показниками Ig A та Ig G простежено їх достовірне підвищення. Рівень Ig А дорівнював $(1,84 \pm 0,03)$ г/л в групі хворих та $(1,36 \pm 0,05)$ г/л в контрольній (р < 0,05). Ig G, відповідно, $(13,96$ $\pm 0,20)$ г/л та $(11,6 \pm 0,35)$ г/л $(\mathrm{p}<0,05)$. Рівень Ig М в обох групах ймовірно не відрізнявся, але в основній групі мав тенденцію до зниження та дорівнював, відповідно, $(1,12 \pm 0,03)$ г/л та $(1,29 \pm$ $0,17)$ г/л (р>0,05).

При вивченні цитокінового профілю у хворих основної групи ми виявили достовірне підвищення рівня прозапальних інтерлейкінів IL-6, IL-8, про- та протизапального IL-4 та туморнекротизуючого фактора (TNFa). Рівень IL-4 був вищим, ніж в контрольній у 2,4 раза, та дорівнював, відповідно, $(4,14 \pm 0,24)$ пг/мл та $(1,73 \pm 0,13)$ пг/мл (р < 0,05). Зіставлення рівнів IL-4 з рівнем CD22, IgG, IgA можна пояснити його впливом на стимуляцію ланки гуморального імунітету як компенсаторну реакцію на виснаження Т-ланки в умовах хронічного запального процесу [2]. Рівень IL-8 було підвищено у 1,9 раза. Його значення дорівнювали $(29,82 \pm 3,15)$ пг/мл в основній групі та $(15,18 \pm$ $1,82)$ пг/мл у контрольній $(\mathrm{p}<0,05)$. Підвищення TNFa - у 3,0 раза зі значеннями $(7,64 \pm 0,93)$ пг/мл проти $(2,55 \pm 0,22)$ пг/мл в контрольній групі (р < 0,05). Рівень IL-6 у хворих з ГК був вищим у 2,7 раза та дорівнював $(3,77 \pm 0,45)$ пг/мл, тоді як у контрольній $-(1,62 \pm 0,15)$ пг/мл (р < 0,05).

Аналіз даних цитокінового профілю дав можливість встановити залежність рівнів IL-6, IL-4 та IL-8 від розповсюдженості ГК та присутності супутнього перифокального запалення. Так, найвищий вміст цитокінів спостерігали у хворих із гігантськими кондиломами Бушке - Левенштейна, 


\section{З ДОСВІДУ РОБОТИ}

які супроводжувалися явищами некрозу, вторинним запаленням, вираженою інфільтрацією тканин. У таких хворих рівень IL-4 коливався (6,74 - 8,64) пг/мл; IL-8 - (104,0 - 140,7) пг/мл; IL-6 (12,90 - 26,91) пг/мл; TNFa - (23,57 - 27,1 ) пг/мл. Тоді як у хворих на одиничні ГК цитокіновий статус не відрізнявся від значень у контрольній груп.

Висновки. Таким чином, у хворих на ГК аногенітальної ділянки мають місце зсуви в ланках клітинного та гуморального імунітету, що проявляються виснаженням ланки клітинного імунітету - загальною лімфопенією, Т-лімфопенією зі зниженням їх абсолютної та відносної кількості в усіх субпопуляціях, підвищенням рівня В-лімфоцитів із достовірним підвищенням Ig G та Ig А. Пропорційне зниження абсолютних та відносних показників пулу лімфоцитів при одночасному достовірному підвищенні ланки В-лімфоцитів та імуноглобулінів у хворих основної групи дає підставу вважати його наслідком впливу ВПЛ на цю ланку.

Достовірне підвищення рівня цитокінів IL-4, IL-6, IL-8 та TNFa у хворих на ГК аногенітальної ділянки відображає ступінь розповсюдження ГК та відповідає характеру перифокального запального процесу, що доцільно використовувати як фактор прогнозування перебігу післяопераційного періоду та ефективності лікування.

\section{СПИСОК ЛІТЕРАТУРИ}

1. Бондаренко Г. М. Застосування місцевих засобів терапії в лікуванні гострокінцевих кондилом (Огляд) / Г. М. Бондаренко, Ю. В. Щербакова // Дерматологія та венерологія. Фаховий журнал. - № 4. - 2014. - С. 5-18.

2. Геряк С. М. Папіломавірусна інфекція як хвороба XXI століття: сучасні підходи до ведення пацієнтів / С. М. Геряк // Медичні аспекти здоров’я жінки. - № 7-2 (48). - 2011. - С. 58-61. 3. Дзюблик I. В. Папіломавірусна інфекція: погляд на проблему лікаря-вірусолога / І. В. Дзюблик, О. В. Ковалюк // Український хіміотерапевтичний журнал. - № 1-2 (25). 2012. - С. 98-106.

4. Протефлазид®: специфическая активность в доклинических исследованиях, эффективность и безопасность применения в клинической практике при заболеваниях, вызванных вирусом папилломы человека (систематический обзор) / В.В. Каминский, М.Н.Шалько, Л. И. Воробьева [и др.] // Здоровье женщины. - 2015. - № 3. - С. 128 - 138.

5. Расчет показателей вариационного ряда. URL: https:// medstatistic.ru/calculators/calcvaries.htm

6. Степаненко Р. Л. Діагностика і комплексна терапія генітальної папіломавірусної інфекції з урахуванням персистенції збудників, особливостей патогенезу, клінічних проявів та перебігу захворювання: автореф. дис. на здобуття наук. ступеня канд. мед. наук: 14.01.20 “Шкірні та венеричні хвороби” / Р. Л. Степаненко ; Національний медичний університет імені О. О. Богомольця. - Київ, 2010. - 25 с.

\section{REFERENCES}

1. Bondarenko, H.M., \& Shcherbakova, Yu.V. (2014). Zastosuvannia mistsevykh zasobiv terapii v likuvanni hostrokintsevykh kondylom (ohliad) [The use of local therapy in the treatment of genital warts (review)]. Dermatolohiia ta venerolohiia. Fakhovyi zhurnal - Dermatology and Venereology. Scientific-practical Professional Journal, 4, 5-18 [in Ukrainian].

2. Heriak, S.M. (2011). Papilomavirusna infektsiia yak khvoroba XXI stolittia: suchasni pidkhody do vedennia patsiientiv [Human papillomavirus infection: as a disease of the XXI century: Modern approaches to patient management]. Medychni aspekty zdorovia zhinky - Medical Aspects of Woman's Health, 7-2 (48), 58-61 [in Ukrainian].

7. Чернікова Л. І. Папіломавірусна інфекція в практиці дерматовенеролога. Огляд літератури / Л. І. Чернікова // Актуальні питання проблеми дерматології, венерології та ВІЛ / СНІД-інфекції: зб. матер. наук. пр. наук.-практ. конфер. (з міжнар. участю), присвяченої 185-річчю професора Бруєва О.Я., 18 - 19 червня 2016 р. Харків : Водний спектр, 2016. - C. 123-133.

8. Фролов В. М. Моноклональные антитела в изучении показателей клеточного иммунитета у больных / В. М. Фролов, И. С. Гайдаш, Н. А. Пересадин // Лабораторное дело. - 1989. - № 6. - C. 71-72.

9. Efficacy of a bivalent LI virus-like particle vaccine in prevention of infection with human papillomavirus types 16 and 18 in young women: a randomised controlled trial / D. M. Harper E. L. Franco, C. Wheeler [et al.] // Lancet. - 2004. - Vol. 364. P. $1757-1765$.

10. Nunes E. M. Epidemiology and biology of cutaneous human papillomavirus / E. M. Nunes, V. Talpe-Nunes L. Sichero // Clinics (Sao Paulo). - 2018. - Vol. 73 (Suppl. 1). - P. e489s.

11. Silins I. Correlates of the spread of human papillomavirus infection / I. Silins, L. Kallings, J. Dillner // Biomarkers Prev. 2000. - Vol. 9. - P. 953-959.

12. Trends in human papillomavirus-associated cancers - United States, 1999-2015 / E. A. Van Dyne, S. J. Henley, M. Saraiya [et al.] // MMWR Morb. Mortal. Wkly. Rep. - 2018. - Vol. 67 (33). - P. 918-924.

3. Dziublyk, I.V., \& Kovaliuk, O.V. (2012). Papilomavirusna infektsiia: pohliad na problemu likaria-virusoloha [Human papillomavirus infection: perspective of virologist]. Ukrainskyi khimioterapevtychnyi zhurnal - Ukrainian Chemotherapeutic Journal, 1-2 (25), 98-106 [in Ukrainian].

4. Kamynskyi, V.V., Shalko, M.N., Vorobeva, L.Y., Romashchenko, O.V., Hrynevych, A.Y. (2015). Proteflazyd®: spetsyfycheskaya aktyvnost $\mathrm{v}$ doklinicheskykh issledovaniyakh, effektivnost i bezopasnost primeneniya $\mathrm{v}$ klinicheskoy praktike pry zabolevaniyakh, vyzvannykh virusom papyllomy cheloveka (systematycheskyy obzor) [Proteflazid®: efficacy and safety in clinical practice for diseases caused by human papillomavirus 


\title{
З ДОСВІДУ РОБОТИ
}

(systematic review)]. Zdorovye zhenshchiny - Health of a Woman, 3, 128- 138 [in Ukrainian].

5. Calculation of variation series indicators. Retrieved from: https://medstatistic.ru/calculators/calcvaries.htm

6. Stepanenko, R.L. (2010). Diagnosis and complex therapy of genital papillomavirus infection taking into account the persistence of pathogens, features of pathogenesis, clinical manifestations and course of the disease. Candidate's Extended abstract. O. Bohomolets National Medical University, Kyiv [in Ukrainian]. 7. Chernikova, L.I. (2016). Papilomavirusna infektsiia v praktytsi dermatoveneroloha. Ohliad literatury [Human papillomavirus infection in the practice of dermatovenereology. Systematic review]. Proceedings of the Conference (with international participation) dedicated to the 185th anniversary of Professor O.Yu. Bruyev "Current issues of dermatology, venereology and HIV/ AIDS infection". Kharkiv, June 18 - 19. 2016 (pp. 123-133). Kharkiv: Vodnyi spektr [in Ukrainian].

8. Frolov, V.M., Haidash, Y.S., Peresadyn, N.A. (1989). Monoklonalnye antytela $\mathrm{v}$ izuchenii pokazateley kletochnogo immuniteta u bolnykh [Monoclonal antibodies in the study of cellular im- munity in patients]. Laboratornoye delo - Laboratory Business, 6, 71-72 [in Russian].

9. Harper, D.M., Franco E.L., Wheeler C, Ferris D.G., Jenkins D.., Schuind A., Zahaf T., et al (2004). Efficacy of a bivalent $\mathrm{L} 1$ virus-like particle vaccine in prevention of infection with human papillomavirus types 16 and 18 in young women: a randomised controlled trial. Lancet, 364, 1757-1765. DOI: 10.1016 / S0140-6736 (04) 17398-4.

10. Nunes, E.M., Talpe-Nunes, V., \& Sichero, L. (2018). Epidemiology and biology of cutaneous human papillomavirus. Clinics (Sao Paulo), 73 (suppl 1). DOI:https://doi.org/10.6061/clinics/2018/e489s

11. Silins, I., Kallings, L., \& Dillner, J. (2000). Correlates of the spread of human papillomavirus infection. Biomarkers Prev., 9, 953-959. DOI: Published September 2000.

12. Van Dyne E.A., Henley, S.J., Saraiya, M., Thomas, C.C., Markowitz, L.E., \& Benard, V.B. (2018). Trends in human papillomavirus-associated cancers - United States, 1999-2015. MMWR Morb Mortal Wkly Rep., 67 (33), 918-924. DOI: http:// dx.doi.org/10.15585/mmwr.mm6733a2

Отримано 05.05.2021

Електронна адреса для листування: deycalo@tdmu.edu.иа

\author{
A. M. SLEPICHKOㄹ, I. M. DEYKALO² \\ Luhansk State Medical University ${ }^{1}$ \\ I. Horbachevsky Ternopil National Medical University²
}

\section{THE FEATURES OF THE CYTOKINE PROFILE AND IMMUNE STATUS IN PATIENTS WITH CONDYLOMAS OF THE ANOGENITAL UNIT}

\begin{abstract}
The aim of the work: to study changes in cellular and humoral immunity in patients with acute condylomas (AC) of the anogenital unit and determine the degree of disorders; to investigate the state of the cytokine profile as predictors of the course of the postoperative period and treatment effectiveness.

Materials and Methods. 105 patients with AC of the anogenital unit were examined: 63 (60\%) women and 42 (40 \%) men. The state of cellular and humoral immunity, the level of cytokines TNFa, IL-4, IL-6, IL-8 were determined.

Results and Discussion. The frequency of chronic somatic pathology was 96 (91.43\%). It was identified a significant decrease in the absolute and relative number of lymphocytes and its T-population. Against the background of lymphopenia, an increase in the level of B-lymphocytes (CD22) was revealed in the absolute and relative amount and concentration of Ig A and Ig G that indicates the presence of a chronic inflammatory process and/or inflammation of viral etiology with depletion of the T-link of immunity. The level of IL-4 was 2.4 higher than in the control group and was equal to $(4.14 \pm 0.24) \mathrm{pg} / \mathrm{ml}$; IL-6 - $2.7-(3.77 \pm 0.45) \mathrm{pg} / \mathrm{ml}$; IL-8 - 1.9 - (29.82 \pm 3.15$) \mathrm{pg} / \mathrm{ml}$; TNFa $-3.0-(7.64 \pm 0.93) \mathrm{pg} / \mathrm{ml}$. It was assessed the dependence level of TNFa, IL-6, IL-4 and IL-8 in the links of cellular and humoral immunity characterized by depletion of the cellular link-general lymphopenia, T-lymphopenia with a decrease in its absolute and relative values in all populations, an increase in the level of B-lymphocytes, IG G and IG A. The increasing levels of cytokines IL4, IL-6, IL-8 and $\mathrm{TNFa}$ in patients reflect the degree of distribution of AC and corresponds to the natural of concominant perifocal inflammation that should be used as a factor in predicting the course of the postoperative period and the effectiveness of treatment.
\end{abstract}

Key words: human papillomavirus; acute condylomas; cytokine profile; immune status. 